\title{
Female Genital Mutilation in Northeastern Nigeria
}

\author{
M. O. Amodu1, M. T. Bolori ${ }^{*}$, A. Kuchichi' ${ }^{2}$ Ibrahim Musa Ngoshe ${ }^{3}$, F. L. Bukar ${ }^{1}$ \\ ${ }^{1}$ Department of Community Medicine, University of Maiduguri, Maiduguri, Nigeria \\ ${ }^{2}$ Department of Sociology and Anthropology, University of Maiduguri, Maiduguri, Nigeria \\ ${ }^{3}$ World Health Organization Borno Office, Maiduguri, Nigeria \\ Email: ^mtbolori@gmail.com
}

How to cite this paper: Amodu, M.O., Bolori, M.T., Kuchichi, A., Ngoshe, I.M. and Bukar, F.L. (2019) Female Genital Mutilation in Northeastern Nigeria. Open Access Library Journal, 6: e5827. https://doi.org/10.4236/oalib.1105827

Received: October 2, 2019

Accepted: November 4, 2019

Published: November 7, 2019

Copyright () 2019 by author(s) and Open Access Library Inc.

This work is licensed under the Creative Commons Attribution International License (CC BY 4.0).

http://creativecommons.org/licenses/by/4.0/

(c) (i) Open Access

\begin{abstract}
Introduction: Different forms of cultural practices are being practiced in $\mathrm{Ni}$ geria and other parts of the world. Some of such are beneficial while others lead to negative impacts. Female genital mutilation as one type of harmful traditional practices is a form of violence against women. Female Genital Mutilation (FGM), practiced in many parts of the world, also known as female circumcision or female genital cutting (FGC), is the practice in which a female child undergoes a process involving the female external genital organ being removed partially or totally for nonmedical reasons, causing a lot of health and other problems during, shortly after the procedure and later in life. Objective: The objective of the study was to understand knowledge and thoughts of women towards female genital mutilation. Method: A cross sectional descriptive study. Results: Most of the respondents were aware of FGM but not as high as in the southern part of Nigeria. The majority knew the meaning of FGM and thought it as a harmful practice done for various reasons. Conclusion: FGM has negative impacts. It is highly recommended for government to enlighten parents more about menace of FGM through community and school health education.
\end{abstract}

\section{Subject Areas}

Public Health, Sociology, Women's Health

\section{Keywords}

Female Genital Mutilation, Behavior, Northeastern Nigeria

\section{Introduction}

Many cultural practices in Nigeria are very useful while others lead to negative 
developments and impacts. Female genital mutilation is one of many forms of violence against women and is considered part of harmful traditional practices [1]. Traditions are established pattern of thought, behavior, action or doing things in a particular community or group identified by ethnicity, religion, geographic location or region [2] [3]. Traditional practices are usually deep rooted passed down through generations and are protected by taboos. Some of such practices are beneficial while others are not and, in some cases, deleterious. World over harmful traditional practices that violate human rights of women are committed variously in different regions [4]. Examples of harmful traditional practices include female genital mutilation, son/gender preference, breast Ironing, bride Kidnapping, forced \& early marriages, forced pregnancy, widowhood rites and female infanticide among others. Female genital mutilation is considered in this study.

Female Genital Mutilation (FGM), also known as female circumcision or female genital cutting (FGC), is the practice in which a female child undergoes a process involving the female external genital organ being removed partially or totally causing injury to the genital organ for nonmedical reasons, whether committed within or outside of medical institution. The procedure can take any of four different types that are practiced or performed on girls of all ages, from infants to adults [4] [5]. The practice occurs in at least twenty-five African countries, as well as in some other parts of the world such as Indonesia, Malaysia, Oman, India, United Arab Emirates and Yemen [4] [5]. The practice also persists within immigrant populations in the Americas, Europe, Australia, and New Zealand. Female Genital Mutilation erroneously believed to ensure virginity before marriage and was used as a means of controlling women's sexuality [4] [5]. Some followers of almost all the major religions of the world such as catholic Christians, Muslims, Coptic Christians Jews, animists are involved in the practice of FGM even though no clear evidence that such practice is mentioned as basic requirement in the text of any of the religions [6]. The claimed advantages of FGM in societies that practiced it include prevention of sexual promiscuity/extramarital sex, preservation of female virginity till marriage, make the female less demanding for sex even after marriage, protection of morals of the women and protect them from rape. Female genital mutilation was also claimed to protect the honor of the families. In some societies, uncircumcised female was considered impure and serves as a potential dishonor to her family [6].

Female circumcision was also believed by some to promote fertility and increase a man's sexual pleasure, both of which enhance a woman's attractiveness in marriage.

In other words, the practice of female genital mutilation was misconceived as useful in the traditional context by many of the members of societies concerned. Some traditional practices such as breastfeeding, social gatherings, settling quarrels and extended family system are believed to be useful [7] [8]. 
Even though some societies see female genital mutilation as virtuous for the victims, spouse and the family in addition to serving as a step for the fulfilment of traditional requirements, there are many reasons why female genital mutilation is evil [9]. Female genital mutilation is gross violation of fundamental human right, unhygienic, very painful, causes severe excruciating pain, induces psychological trauma, leads to hemorrhage (severe bleeding) or death, leads to loss of self confidence in the victims and may lead to many gynecological and obstetric complications such as infertility, difficulties at child birth among others. Some health care professionals who are expected to have capacity to identify, prevent and/or manage the menace of FGM were found to be themselves part of the problem in some parts of Africa [10]. The World Health Organization strongly condemns health workers participation in conducting FGM.

The WHO classifies health risks of FGM into short term, long-term categories and obstetric complications [11]. The short-term health risks include Severe pain during and after the procedure, excessive bleeding that may lead to shock. Both pain and bleeding can lead to shock. Other short-term complications include, genital tissue swelling, Infections with bacteria that may ascend to kidneys to cause kidney damage and/or failure, infection with other germs such as $\mathrm{Hu}$ man Immunodeficiency Virus (HIV). Urination problems such as painful urination or inability to pass urine, worst among the short-term health risks can lead to death.

The long-term risks include pain as a result of damage to the tissues and nerves. Other long-term risks are chronic genital infections associated with chronic genital pain, vaginal discharge, itching sensations, cysts, abscesses [11]. Genital ulcers may heal with scar formation and may lead to keloids. Chronic reproductive tract infections may lead to inability to conceive. Long term urinary tract infections can lead to chronic kidney disease or chronic kidney failure. Long term health risk may include menstrual disorders due to blockage of the vaginal opening that may be associated with painful sex. Decreased sexual pleasure or desire, poor lubrication of vagina may leave victim with painful sexual experience, lack of orgasms and lack of satisfying or gratifying sex. In other words, a female can lose sexual health being a victim of FGM. Obstetric complications of FGM include high chances of Caesarean section in child birth. A victim of FGM has increased risk of bleeding after child birth, difficult or prolonged labor, lacerations, tears and long hospital stay.

\section{Knowledge, Attitude and Practice of Female Genital Mutilation}

Harmful traditional practices are still prevalent in Nigeria including FGM despite domestic laws prohibiting such practices [12]. The prevalence of FGM actually increased from 19\% in 2003 to $25 \%$ in 2013 in Nigeria [12]. Although female genital mutilation is illegal in Nigeria, it remained practiced among commoners as well as health workers [12]. In a study conducted in Benin city, Nige- 
ria, out of 193 nurses who responded to questionnaire on FGM, about 80 (44\%) were themselves victims of female circumcision [12]. Five respondents $(2.8 \%)$ were of the opinion that FGM was a good practice. Twelve respondents $(6.6 \%)$ with 20 or more years of experience in nursing were in the habit of routinely providing the service of FGM to clients on demand because as part of their culture [12]. Eight (4\%) of the respondents would have their daughters circumcised. All of the respondents were aware of FGM and more than half were aware that complications of FGM include hemorrhage, problems with labor, genital injuries, infections and keloid formation [12] [13].

Another study conducted in Benin city of Nigeria showed that out of 325 women involved as respondents, almost all were aware of FGM [14]. Their main sources of knowledge were school (49\%) and family (39\%).

\section{Justification for Study}

Paucity of data on the subject has been evident in Nigeria especially in the northern part. Harmful traditional practices were noted to be prevalent in Nigeria including FGM among the adult population [9]. The prevalence of FGM actually increased from $19 \%$ in 2003 to $25 \%$ in 2013 in Nigeria [12].

\section{Objectives of Study}

The objective of the study was to understand the knowledge and thought of women towards female genital mutilation.

\section{Methodology}

The north-east region is one of the six geopolitical zones of Nigeria comprising of six states that include Borno, Adamawa, Gombe, Bauchi, Taraba and Yobe states [15]. The similarities of cultures and behaviors of the people in each of the regions were exploited to create the zone to ease administration in the country. The estimated population in the north east zones was about 18 Million people [16]. Maiduguri metropolis, capital of Bornoand Jere town (contiguous with the state capital) was selected for the study on the basis of convenience sampling. Maiduguri lies within the geographic area defined by latitudes 11.84692, 13.15712 [17]. Maiduguri and Jere towns are almost inseparable in terms of the boundaries and movements of their residents in and around the areas, hence taken together as one in this study. There were diverse ethnic groups in the area of the study out of which the Kanuris were the most populous. Islam and Christianity were the two main religions within the study areas in particular and Borno in general.

Research design was cross sectional descriptive study conducted over period of 8 weeks from beginning of June 2015. The target population was all female above 18 years of age, old enough to respond to questions reasonably well. Sample size was estimated using the Kish Leslie formula meant for populations greater than 10,000 [18]. Sampling was done by multistage. Women were sam- 
pled in two residential areas and maternity departments of two of the major hospitals (Teaching hospital and Government State Specialist Hospital) in Maiduguri/Jere area. These areas were selected by convenience. Data were collected using interviewer administered questionnaire as a tool. The interviewers were given a short training to orient and familiarize them with the questions so that all have common understanding. The interviewers were also told to be courteous, respectful and considerate of the traditions and cultures while visiting and eliciting response to the questions. Response to each question was further probed by the interviewer to confirm or authenticate that response was what respondent truly intended to give and not just arbitrary. The questionnaire contains open and close ended question types. Households in the residential areas were systematically sampled while respondents in each household were sampled by simple random sampling technic. Respondents in the health facilities were sampled by systematic random sampling technics as they register for consultations.

Each of the respondents was asked in simple language using any of the local dialects applicable in each case including use of interpreters where necessary. Questionnaire was used as question guide as well as document to capture each of the responses.

The questionnaire seeks to elicit information on respondents' profiles, levels of knowledge, thoughts on FGM in terms of age, level of education, marital status, employment, level of education and number of children. It also captures responses as to why as well as at what age FGM is being conducted.

The result from the research was analyzed using simple Microsoft excel to make tables and graphs.

\section{Exclusion Criteria}

The following criteria were adopted as exclusion criteria-visitors to the area of study or strangers or those on mission to the area of study, persons too old with memory problems or very sick were also excluded. Persons that were uninterested or those perceived as biased by interviewer were excluded.

\section{Ethical Clearance}

Ethical clearance was obtained from the ethical committee of the University of Maiduguri Teaching Hospital that has the area of the study as catchment area. Before participating each respondent was ensured to have understood the purpose of the research and have signed the consent form.

\section{Limitation of Study}

Only females were considered in the study. Females were the victims but males were usually the key decision makers in the society [6].

The study considered respondents in urban areas only. The questions were few. 


\section{Results}

\section{Discussions}

The majority (40.5\%) of respondents were aged between 20 and 29 years, married (67.9\%) and many had completed one level education (49.8\%). Very few $(0.8 \%)$ farmers were interviewed because the study was conducted in the urban areas. More details of description of respondents can be seen in Table 1. Almost all $(94.1 \%)$ heard about female circumcision or genital cutting to show that the practice actually exists in the society. Apart from just hearing, about $82.5 \%$ knew

Table 1. Description of respondents.

\begin{tabular}{|c|c|c|}
\hline Socio-demographic characteristics & Frequency & Percentage (\%) \\
\hline \multicolumn{3}{|l|}{ Age in years $(\mathrm{n}=378)$} \\
\hline$<20$ & 106 & 26.5 \\
\hline $20-29$ & 162 & 40.5 \\
\hline $30-39$ & 82 & 20.5 \\
\hline$\geq 40$ & 28 & 7.0 \\
\hline \multicolumn{3}{|l|}{ Marital status $(\mathrm{n}=325)$} \\
\hline Married & 271 & 83.4 \\
\hline Divorced & 17 & 5.2 \\
\hline Separated & 4 & 1.2 \\
\hline Widowed & 22 & 6.8 \\
\hline Single & 11 & 3.4 \\
\hline \multicolumn{3}{|l|}{ Level of education $(n=400)$} \\
\hline None & 17 & 4.3 \\
\hline Quranic & 22 & 5.5 \\
\hline Primary & 79 & 19.8 \\
\hline Secondary & 81 & 20.2 \\
\hline Tertiary & 199 & 49.8 \\
\hline Others & 2 & 0.5 \\
\hline \multicolumn{3}{|l|}{ Occupation $(n=400)$} \\
\hline Civil servant & 117 & 29.2 \\
\hline Trader & 48 & 12.0 \\
\hline Farmer & 3 & 0.8 \\
\hline Teacher & 31 & 7.8 \\
\hline Seamstress & 41 & 10.2 \\
\hline Student & 40 & 10.0 \\
\hline Housewife & 120 & 30.0 \\
\hline \multicolumn{3}{|l|}{ Number of children $(n=400)$} \\
\hline $1-4$ & 169 & 42.2 \\
\hline $5-8$ & 82 & 20.5 \\
\hline$\geq 9$ & 28 & 7.0 \\
\hline 0 & 121 & 30.3 \\
\hline
\end{tabular}


more about female genital cutting somewhat less than the proportion obtained in other studies where almost all interviewed were aware of female circumcision [12] [13] [14]. Though, specific question on complications of FGM was not asked, $81.5 \%$ of the respondents admitted that the practice was a harmful one. In the study conducted in Benin, more than half of the respondents knew that FGM could cause excessive bleeding, problems with labor, proneness to infections and scar formation [13] [14]. Table 2 shows that about $22.1 \%$ of respondents thought FGM to be a common practice in the society. That can be compared to the prevalence in Nigeria as stated in a study by Onuh and group in which it was stated that FGM prevalence grew from 19\% in 2003 to 25\% in 2013 [12]. This shows that very few $18.5 \%$ or less might have misperceived FGM as having any benefit [6].

Reasons given to account for the practice of FGM by respondents were mainly to prevent promiscuity (36\%) as in Figure 1. Next to that reason given was because of traditional rites. Another important reason given was for the purpose of

Table 2. Behavior respondents towards female genital mutilation among.

\begin{tabular}{lccc}
\hline & & Frequency & Percentage (\%) \\
\hline Have you heard of female circumcision? $(\mathrm{n}=387)$ & Yes & 364 & 94.1 \\
Do you know what of female genital mutilation & No & 23 & 5.9 \\
means? $(\mathrm{n}=366)$ & No & 302 & 82.5 \\
$\begin{array}{l}\text { Do you think female genital mutilation harmful } \\
\text { traditional practice? ( } \mathrm{n}=369)\end{array}$ & Yes & 301 & 17.5 \\
Do you think female genital mutilation is part of & No & 68 & 81.5 \\
practices among your people? ( $\mathrm{n}=389)$ & No & 86 & 17.0 \\
\hline
\end{tabular}

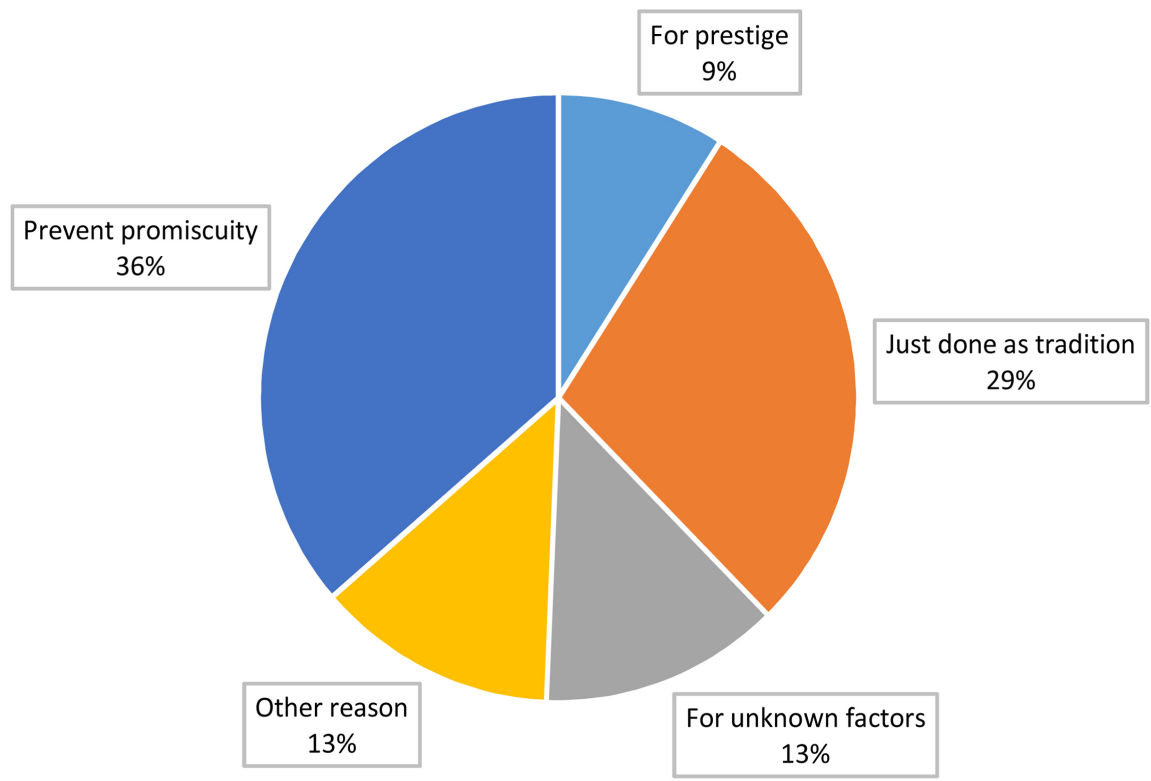

Figure 1. Reasons for practice of female genital cutting according to respondents $(\mathrm{n}=$ 366). 


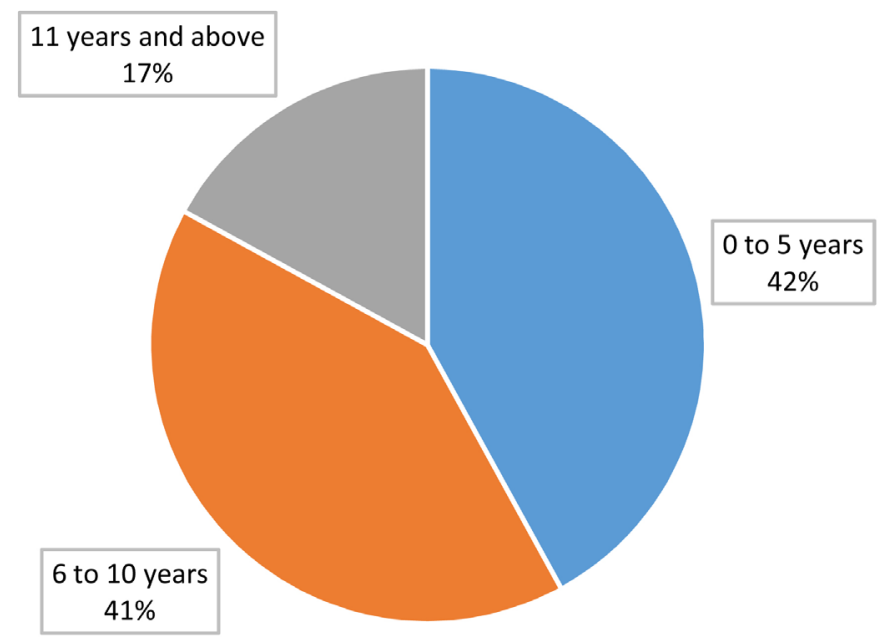

Figure 2. Ages at which female genital cutting is done according to respondents $(\mathrm{n}=366)$.

prestige. Other reasons were given by $13 \%$ and another $13 \%$ for unknown reasons. All the reasons given could be related to one another in the sense that they are all useful in adding value to the woman by ensuring virginity till marriage, adding more prestige or honor to victim and family and more. These are similar to the findings of other studies that found reasons related to the same issues [6] [7] [8]. Other reasons given as mentioned in the literature were that of making a woman's chances of getting married higher because female circumcision aids in making a woman more attractive to men by being more prestigious with more sexual pleasures to give to her husband in marriage. Females that were circumcised were believed to be purer than the others [6].

The age at which respondents thought female circumcision was conducted were 0 to 5 years (42\%), 6 to 10 years (41\%), 11 years and above (17\%) as shown in Figure 2. The study shows that majority of the FGM was committed before the victims reach maturity or before attaining age within which they could comprehend reasonably and decide for themselves. The parents were the ones that decide for the children to have circumcision or not. In Southern part of Nigeria, about $6.6 \%$ of experienced nurses were in habit of providing female circumcision services and about $4 \%$ were with the habit of circumcising their own daughters [12]. The fact some health workers being involved in the practice of FGM could actually contribute to parents' belief that the practice is good.

\section{Recommendations}

Mothers should strongly be advised against the practice of FGM in antenatal and other relevant clinics.

Health workers especially nurses not to practice any form of harmful traditional practices especially FGM. No room should be allowed for any health worker to aid or encourage any in FGM.

The government to introduce programs through the media houses to educate 
people against the practice of female genital cutting.

The law banning the practice of FGM should be seriously enforced for all involved to account for practice of FGM.

Traditional and religious leaders to well be tasked to enlighten families against FGM.

\section{Conflicts of Interest}

The authors declare no conflicts of interest regarding the publication of this paper.

\section{References}

[1] Kering Foundation (2018) Harmful Traditional Practices. http://www.keringfoundation.org/harmful-traditional-practices

[2] Republic of Turkey Ministry of Education (2018) http://www.kultur.gov.tr/EN-98606/common-usage-custom-tradition-and-conventi on.html

[3] Merriam Webster (2018) https://www.merriam-webster.com/dictionary/tradition

[4] The Advocates for Human Rights. Stop Violence against Women (2010) Types and Prevalence of Harmful Practices. http://www.stopvaw.org/harmful_practices_types_prevalence

[5] Program for Appropriate Technology in Health (1997) The Fact. Female Genital Mutilation. https://path.azureedge.net/media/documents/path_the_facts_fgm.pdf

[6] Female Genital Mutilation (2019) Information for Health \& Child Protection Professionals. http://www.fgm.co.nz/beliefs-and-issues/\#religion

[7] Gebrekirstos, K., Abebe, M. and Fantagun, A. (2013) A Cross Sectional Study on Factors Associated with Harmful Traditional Practices among Children Less Than 5 Years in Axum Town, North Ethiopia.

[8] Eshemokha, U. (2017) Culture and Health: Beneficial Cultural Practices in Nigeria. http://www.nimedhealth.com.ng/main-website/culture-and-health-beneficial-cultur al-practices-in-nigeria/

[9] Okeke, T.C., Ezenyeaku, C.C.K. and Anyaehie, U.S.B. (2012) An Overview of Female Genital Mutilation in Nigeria. Annals of Medical and Health Sciences Research, 2, 70-73. https://doi.org/10.4103/2141-9248.96942

[10] Kaplan, A., Hechavarría, S., Bernal, M. and Bonhoure, I. (2013) Knowledge, Attitudes and Practices of Female Genital Mutilation/Cutting among Health Care Professionals in The Gambia: A Multiethnic Study. BMC Public Health, 13, 851.

http://www.biomedcentral.com/1471-2458/13/851 https://doi.org/10.1186/1471-2458-13-851

[11] World Health Organization (2019) Health Risks of Female Genital Mutilation. https://www.who.int/reproductivehealth/topics/fgm/health_consequences_fgm/en/

[12] Onuh, S.O., Igberase, G.O., Umeora, J.O.U., Okogbenin, S.A., Otoide, V.O. and Gharoro, E.P. (2006) Female Genital Mutilation: Knowledge, Attitude and Practice among Nurses. Journal of the National Medical Association, 98, 409-414. https://www.ncbi.nlm.nih.gov/pmc/articles/PMC2576104/

[13] Dalal, K., Kalmatayeva, Z., Mandal, S., Usataveva, G., Lee, M.S. and Biswas, A. (2018) Adolescent Girls' Attitudes toward Female Genital Mutilation: A Study in Seven African Countries. F1000Research, 7, 343. 
https://www.ncbi.nlm.nih.gov/pmc/articles/PMC6008845/

[14] Adesoye, A.O. and Adelosoye, A. (2018) Awareness and Knowledge of Female Genital Mutilation among Women in a Sub-Urban Community in Edo State, Nigeria. Annals of Biomedical Sciences, 15.

https://www.ajol.info/index.php/abs/article/view/133605

[15] Yahaya, A. (2018) The Six Geo-Political Zones n Nigeria and Their States. Nigerian Infofinder. https://nigerianinfofinder.com/geopolitical-zones-in-nigeria/

[16] United Nations Development Program (UNDP) (2017) Business Case Assessment for Accelerating Development Investments in Famine Response and Prevention. https://www.undp.org/content/dam/undp/library/crisis\%20prevention/UNDP_Fam ineStudy_Nigeria.PDF

[17] Latitude longitude (2019) Maiduguri, Nigeria Latitude Longitude. https://latitudelongitude.org/ng/maiduguri/

[18] Araoye, M.O. (2004) Research Methodology with Statistics for Health for and Social Sciences. Nathadex Publishers, Kwara, Nigeria. 